logos_i_ethos_2016_(40)_numer_specjalny_1, s. 105-121

DOI: http://dx.doi.org/10.15633/lie.1702

Paulina Wąż

Uniwersytet Papieski Jana Pawła II w Krakowie

\title{
Szczęście i radość jako rezultat kłamstwa
}

Pojęcie szczęścia wydaje się zrozumiałe dla wszystkich. Każdy z nas pragnie być szczęśliwy i dąży do osiągnięcia tego stanu. W tym momencie nasuwa się rozumienie szczęścia wskazane przez Zygmun-

Paulina Wąż, mgr filozofii, doktorantka w Katedrze Filozofii Społecznej i Polityki Uniwersytetu Papieskiego Jana Pawła II w Krakowie. Zainteresowania naukowe: filozofia kłamstwa, etyka personalistyczna, filozofia polityki, konsumpcjonizm. ta Freuda: „[...] czego ludzie żądają od życia, co chcą osiągnąć (?) Nie sposób pomylić się odpowiadając na to: ludzie dążą do szczęścia, chcą je osiągnąć i utrzymać stan życia w szczęściu”" To stwierdzenie wydaje się słuszne, jednak bardzo często trudno określić, czym jest szczęście, do którego dążymy. W odpowiedzi zazwyczaj pojawiają się przykłady rzeczy uznawanych za wartościowe. Człowiek intencjonalnie wie, że pewnych rzeczy oczekuje, innych zaś unika, jedne sytuacje sprawiałyby radość, inne wręcz przeciwnie ${ }^{2}$. Jednak niezależnie od tego, jakim stanem okaże się szczęście, należy zgodzić się, że jest to stan dobry, o który warto zabiegaćs

Celem pracy będzie zastanowienie się nad szczęściem i radością wypływającą z kłamstwa i okłamywania. Fenomenologiczne podejście do kłamstwa zostanie opisane w oparciu o myśl Wojciecha Chudego oraz analizę kłamstwa w biznesie autorstwa Jarosława Kucharskiego. Warto zastanowić się, dlaczego kłamiemy. Bo kłamstwo jest atrakcyjne i kolorowe, a prawda szara i tylko jedna, nudna.

S. Freud, Kultura jako źródło cierpień, tłum. J. Prokopiuk, Warszawa 1995, s. 20.

2 Por. N. White, Filozofia szczęścia od Platona do Skinnera, tłum. M. Chojnacki, Kraków 2008, s. 11 .

N. White, Filozofia szczęścia od Platona do Skinnera, dz. cyt., s. 13. 
Według słownikowej definicji kłamstwo oznacza oczywiście stwierdzenie niezgodności z rzeczywistością, kierowanie się zamiarem wprowadzenia kogoś w błąd ${ }^{4}$. Ta definicja wpisuje się w rozważania Wojciecha Chudego, który pisze, że kłamstwo to „wprowadzenie rzeczy we własnym przekonaniu fałszywych" oraz „świadome wprowadzenie kogoś w błąd”. Po pierwsze kłamstwo określone jest jako sprzeczność pomiędzy tym, co mówimy, a tym, co myślimy, oraz kolejno jako celowe oszukanie drugiej osoby. Kłamstwo to oczywiście działanie celowe, a nie tylko przypadkowa pomyłka czy przejęzyczenie. Przeciwieństwem kłamstwa jest prawdo-

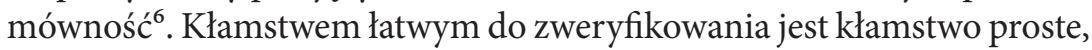
czyli codzienne, proste zaprzeczenia rzeczywistości.

Kłamanie wydaje się łatwe, jednak jest aktem trudnym, gdyż obciąża umysł kłamcy. Kłamca jest przy tym bardziej uprzywilejowany niż jego słuchacze, ponieważ wie, co jest kłamstwem, a co prawdą, ale z drugiej strony musi być czujny, aby zachować niesprzeczność w wypowiadanych przez siebie sądach. Kłamstwo to tworzenie fikcji, przekraczanie rzeczywistości, co wymaga wiele wysiłku, wyobraźni i panowania nad kontekstem fikcyjnym wobec faktów. Wymaga także zdolności przewidywania konsekwencji, jak treść zostanie odebrana przez naszego rozmówcę. W akcie kłamania musimy ciągle kreować świat i brnąć coraz to głębiej w fikcję, ponieważ „kłamstwo rodzi kłamstwo”. Uruchamia się lawina, którą trudno powstrzymać

Co ciekawe, Chudy uważa, że celowe oszukanie jest trudniejsze od mówienia prawdy, ponieważ kłamca, obciążając umysł, musi zabezpieczyć w nim każdorazowo wszystko to, co jest zgodne z prawdziwym stanem rzeczy $^{8}$. Kłamca musi mieć dobrą pamięć i być dobrym aktorem. Tworzenie fikcji wymaga od kłamcy wiele wysiłku i wyobraźni oraz panowania nad całym kontekstem fikcyjnym wobec prawdziwej rzeczywistości.

\footnotetext{
4 Por. Stownik języka polskiego, red. M. Szymczak, Warszawa 1978, s. 938.

5 Por. W. Chudy, Filozofia kłamstwa. Kłamstwo jako fenomen zła w świecie osób i społeczeństw, Warszawa 2003, s. 110.

6 Por. W. Chudy, Filozofia kłamstwa..., dz. cyt., s. 34.

7 Por. W. Chudy, Filozofia kłamstwa..., dz. cyt., s. 42-46.

8 Por. W. Chudy, Filozofia kłamstwa..., dz. cyt., s. 33.
} 
Gdy spełnia takie warunki, to kłamstwa przekazywane przez niego są trudne do zdemaskowania, jednak kłamca musi udawać we wszystkim, co mówi, ponieważ w wypadku ujawnienia jego fałszywych sądów nie ucieknie od konsekwencji ${ }^{9}$.

Według Wojciecha Chudego kłamstwo jest zakorzenione w języku, dlatego duże znaczenie dla istoty kłamstwa ma komunikat. Komunikat według autora ma dwa założenia: po pierwsze powinien zakładać wolność nadawcy w tworzeniu komunikatu i wolność odbiorcy w nienarzucanym sposobie odebrania komunikatu. We właściwym komunikacie wybór odbiorcy i nadawcy jest identyczny. Natomiast kłamca w tym momencie będzie dążył do zniewolenia swojego odbiorcy. Drugim założeniem komunikatu jest prawdomówność. Jak łatwo zauważyć, oczywiście kłamstwo neguje oba założenia ${ }^{10}$.

Należy pamiętać, że kłamstwo jest trudne, ale można je zdemaskować, ponieważ oprócz narządu mowy posługujemy się mową ciała. To właśnie komunikat werbalny może zakomunikować odbiorcy, że przekazywane treści to kłamstwa ${ }^{11}$. Obecnie rozwój wszelkich technologii ułatwia nam okłamywanie innych. Porównajmy wysłany SMS z zafałszowaną wiadomością, dla przykładu zawierającą jakieś proste kłamstwo: „Jak się masz?” - „U mnie wszystko w jak najlepszym porządku, mam się świetnie”, i tę samą wiadomość przekazaną twarzą w twarz. Łatwiej oszukać, okłamać kogoś przez telefon, wirtualnie.

Chudy uważa, że kłamstwa trudno zdemaskować, ludzie niezbyt sobie radzą z ich rozpoznawaniem. Co ciekawe, kłamstwa uczymy się od najmłodszych lat, już od rodziców czy nauczycieli. Na przykład dzięki stwierdzeniom typu: „Przeproś koleżankę z klasy i powiedz, że wcale nie myślisz, że jest głupia”, czyli przez tak zwane kłamstwa grzecznościowe, którymi posługujemy się codziennie. Za takie kłamstwa jesteśmy nawet wynagradzani. Można stwierdzić za Wojciechem Chudym, że kłamstwo ma „nogi za stali”. Niektóre kłamstwa są nawet niezbędne do codziennego

J. Antas, O kłamstwie i kłamaniu, Kraków 2000, s. 15-29.

10 Por. W. Chudy, Filozofia kłamstwa..., dz. cyt., s. 42-45.

11 Por. W. Chudy, Filozofia kłamstwa..., dz. cyt., s. 46. 
funkcjonowania w społeczeństwie. Do tej grupy kłamstw zalicza się między innymi właśnie kłamstwa grzecznościowe. Codziennie posługujemy się różnymi rodzajami kłamstw, jednak nie każde kłamstwo ma złe intencje. Gdy ktoś nam mówi: „Dzień dobry”, odpowiadamy zgodnie z zasadami grzecznościowymi: „Dzień dobry”, nie zastanawiając się nad ustalaniem prawdy czy fałszu naszej wypowiedzi. Nie sposób wyobrazić sobie funkcjonowanie w społeczeństwie bez kłamstw grzecznościowych, bez tego niezbędnego, jak się okazuje, mijania się z prawdą, co wielokrotnie może uszczęśliwić nas lub innych ${ }^{12}$.

Nawet z badań socjologów wynika, że każdy człowiek kłamie przeciętnie dwa razy w ciągu dnia. Do najczęstszych codziennych kłamstw zalicza się kłamstwa grzecznościowe typu: „nie wiem, co się stało”, „wyglądasz wspaniale”, „na pewno oddzwonię”. Co ciekawe, bardzo często kłamstwa grzecznościowe nie są uważane za kłamstwo ${ }^{13}$, więcej nawet mogą poprawić czyjś humor, uszczęśliwić kogoś. Takie kłamstwa uprzejmościowe, tzw. niewinne kłamstewka, aby oszczędzić komuś przykrości, są znane nawet małym dzieciom. Umiejętność kłamania, gdy sytuacja tego wymaga, jest ważnym elementem socjalizacji i umożliwia trwanie grup społecznych.

Za Ervingiem Goffmanem nasze codzienne kłamstwa można nazwać „teatrem życia codziennego", ponieważ każdy z nas spełnia różne role w swoim życiu, musi być dobrym aktorem, i oczywiście nie chodzi tylko o role zawodowe. Niektóre z tych ról wręcz wymagają przekazywania błędnych informacji ${ }^{14}$. Co więcej, takie kłamstwa są bardzo często akceptowane i dopuszczalne, a nawet zalecane, aby nie sprawić innym przykrości albo dać odrobinę szczęścia i radości chociaż z fałszywego komplementu lub fałszywej grzeczności.

Ciekawym przykładem, w którym wykorzystuje się kłamstwo, jest sytuacja zdobywania i utrzymania partnera. Podczas uwodzenia każdy

12 Por. T. Witkowski, Psychologia kłamstwa. Motywy - strategie - narzędzie, Warszawa 2002, s. 91-96.

13 Por. T. Witkowski, Psychologia kłamstwa..., dz. cyt., s. 137.

14 Por. E. Goffman, Człowiek w teatrze życia codziennego, tłum. H. Danter-Śpiewak, Warszawa 2000, s. 58. 
chce przedstawić siebie z jak najkorzystniejszej strony, bardzo często prezentuje siebie znacznie lepszym niż jest w rzeczywistości. Oczywiste jest, że kobieta chce się zaprezentować jako bardziej atrakcyjną, z tego powodu nakłada makijaż, aby ukryć wszelkie mankamenty urody. Z kolei mężczyzna bardzo często przedstawia siebie jako bardziej opiekuńczego i zaradnego, niż jest w rzeczywistości - wszystko, by zdobyć swoją wybrankę ${ }^{15}$. Kobiety niekiedy dają mężczyznom złudne poczucie wyższości, aby dowartościować ich podczas rytuału uwodzenia. W tych okolicznościach kłamstwa są powszechnie akceptowane, zarówno na swój temat, jak również na temat uwodzonej osoby. Oczywiście cały czas obracamy się w kręgu tzw. „niewinnych kłamstewek”, kłamstw grzecznościowych, dzięki którym możemy sprawić drugiej osobie radość lub uniknąć przykrości.

Do najbardziej podstawowych form kłamstwa zalicza się triadę św. Tomasza z Akwinu, który wyróżnia trzy rodzaje kłamstw, na których kolejno opiera swoje rozważania Wojciech Chudy. Należy pamiętać, że św. Tomasz uznaje całkowity zakaz kłamstwa, jako że wyrządza ono wiele szkody, a przede wszystkim jest wypowiadaniem czegoś sprzecznego z naszymi myślami. Święty Tomasz uważa, że jeśli którykolwiek z czynników kłamstwa jest zły, to cały czyn jest moralnie zły ${ }^{16}$. W swych rozważaniach wyróżnia, jak już wspomniano, trzy podstawowe rodzaje kłamstwa. Po pierwsze kłamstwo niegodziwe, które według niego jest zawsze zakazane, a jego celem jest zaszkodzenie drugiemu i oderwanie go od prawdy. Osoba okłamana ma ponieść jak największą szkodę. Celowe wyrządzanie komuś krzywdy zwiększa naszą winę, tym bardziej jeśli celem jest uszczęśliwienie siebie kosztem drugiego ${ }^{17}$. Dodatkowo Chudy podkreśla, że kłamstwo niegodziwe neguje godność osoby ludzkiej ${ }^{18}$. Po drugie św. Tomasz wyróżnia kłamstwa żartobliwe, które nie czynią żadnej szkody, ale mają ubarwić rzeczywistość. To wszelkiego rodzaju dowcipy i żarty, które ków 2014, s. 141.

15 Por. J. Kucharski, Usprawiedliwione kłamstwo we współczesnej etyce stosowanej, Kra-

16 Por. św. Tomasz z Akwinu, Suma teologiczna, t. 20, tłum. F. W. Bednarski, Londyn 1972, s. 65 .

17 Por. św. Tomasz z Akwinu, Suma teologiczna, dz. cyt., s. 63n.

18 Por. W. Chudy, Filozofia kłamstwa..., dz. cyt., s. 77n. 
poprawiają nam humor. W tym wypadku ma się na celu dobro przyjem$n \mathrm{e}^{19}$. Kłamstwo żartobliwe wykorzystuje formy wyolbrzymienia, barwne opisy, których celem jest zabawa, zaspokojenie potrzeb psychologicznych $^{20}$. Po trzecie - kłamstwo obronne, do którego człowiek ucieka się, aby obronić wyższą wartość niż prawda. Można by doń zaliczyć na przykład ukrywanie osób prześladowanych podczas II wojny światowej. Chroni się w ten sposób wartość życia. Kłamstwa takie zalecane są w sytuacjach ekstremalnych, właśnie w obronie życia. W tym wypadku im większe zamierzenie dobra, tym mniejsza wina kłamcy ${ }^{21}$. Według Wojciecha Chudego znaczenie i powagę kłamstwa obronnego podkreślają sytuacje, w których trzeba posłużyć się kłamstwem, aby obronić inne, wyższe wartości. Ten rodzaj kłamstwa powinien być używany w sytuacjach ostatecznych, gdyż osoba posługująca się kłamstwem obronnym bierze na siebie ciężar grzechu. Niezareagowanie także byłoby grzechem i dodatkowo utratą wartości, jednak kłamstwo obronne to nadal akt wprowadzenia drugiej osoby w błąd, celowe oszukanie kogoś, z czego wynika, że kłamstwo obronne to nadal kłamstwo, jednak jego dopuszczalność likwiduje zasadę absolutnego zakazu kłamstwa według Chudego ${ }^{22}$.

Inne, również ciekawe, formy kłamstwa wyróżnia profesor Wojciech Chudy, który do najbardziej podstawowych (oprócz trzech wymienionych za św. Tomaszem z Akwinu) zalicza półprawdę, omyłkę, przemilczenie oraz plotkę i autokłamstwo. Według Wojciecha Chudego analiza podstawowych rodzajów kłamstwa ujawnia również charakterystykę innych, rzadziej spotykanych kłamstw, jak na przykład pochlebstwo, krętactwo, intryga itd.

Po pierwsze istotą półprawdy jest ukrycie części informacji. Jedna część przekazanego sądu będzie prawdziwa, jednak druga - zafałszowana. Dlatego półprawdę określa się jako całe kłamstwo, chociaż nie cały sąd zostaje zakłamany. Półprawda jest najczęstszą formą kłamstwa. W życiu

\footnotetext{
19 Por. św. Tomasz z Akwinu, Suma teologiczna, dz. cyt., s. 63n.

20 Por. W. Chudy, Filozofia kłamstwa..., dz. cyt., s. 77n.

21 Por. św. Tomasz z Akwinu, Suma teologiczna, dz. cyt., s. 63n.

22 Por. W. Chudy, Filozofia kłamstwa..., dz. cyt., s. 78.
} 
codziennym często posługujemy się takim typem kłamstwa, opuszczając nieistotne lub szkodliwe według nas informacje ${ }^{23}$. Kolejnym rodzajem kłamstwa jest omyłka. Chociaż zachodzi nieświadomie, to została usytuowana przez Chudego w dziedzinie kłamstwa, ponieważ bardzo często działa na zasadzie plotki, a adresat uznaje za wartość wyższą od prawdomówności korzyści płynące z podania fałszu ${ }^{24}$. Natomiast przemilczenie to ukrycie części istotnej informacji. Stosowane bardzo często w codziennym życiu, aby nie obrazić drugiej osoby, nie przeszkodzić jej czy nie zdenerwować, nie sprawić jej przykrości, jak również aby sprawić jej radość. Jednak przemilczenie może dotykać także drugich osób i mieć na celu pogrążenie ich ${ }^{25}$. Dobry kłamca kłamie tak, że osoba okłamana wierzy mu i nie zadaje dodatkowych pytań. Celem przemilczenia będzie przekazanie informacji tak, aby zostały błędnie odebrane. Kłamca pozwala, aby jego odbiorca wyobraził sobie i dopowiedział resztę zdarzeń czy informacji. Jednak w sytuacji, gdy prawda zostanie wykryta, nie ufamy już kłamcy i weryfikujemy jego wypowiedzi ${ }^{26}$.

Kolejnym bardzo ciekawym rodzajem kłamstwa jest autokłamstwo, czyli oszukiwanie samego siebie. W życiu każdy odgrywa różne role i pragnie być szczęśliwy, a tutaj już tylko krok do autokłamstwa. Oszukiwanie siebie może występować w najdoskonalszej dla siebie formie. Wojciech Chudy pisze: „w przypadkach ekstremalnych oszukiwanie sprawia, że mówimy nieprawdę z uczuciem szczerości” ${ }^{27}$. W takich okolicznościach wydaje się, że zostaje przekazana prawdziwa informacja, jednak jest to kłamstwo, w które sami uwierzyliśmy. Pojawia się wówczas ryzyko tkwienia $\mathrm{w}$ autoiluzji, ponieważ oszukiwanie siebie stanie się łatwym sposobem na radzenie sobie z problemami. Ludzie w swoim życiu czują się często bezradni i niepewni, co popycha ich do oszukiwania siebie, wyzbywania się prawdy o sobie, aby sprostać wymogom różnych

\footnotetext{
23 Por. W. Chudy, Filozofia kłamstwa..., dz. cyt., s. 62.

24 Por. W. Chudy, Filozofia kłamstwa..., dz. cyt., s. 63.

25 Por. W. Chudy, Filozofia kłamstwa..., dz. cyt., s. 64.

26 Por. S. B. Walters, Kłamstwo cała prawda o... Jak wykryć kłamstwo i nie dać się oszukać, tłum. E. Jusewicz-Kalter, Gdańsk 2003, s. 20n.

27 W. Chudy, Filozofia kłamstwa..., dz. cyt., s. 410.
} 
światopoglądów i modeli życia. W ten sposób popada się w autokłamstwo, staje się kimś innym, niż się jest ${ }^{28}$. Codzienne drobne autooszustwa to tylko autokłamstwa naiwne, które zadowalają nas na krótki czas. Takie zachowanie może doprowadzić do autokłamstwa totalnego, czyli rutynowego samooszukiwania siebie, aby ułatwić i ubarwić sobie codzienną rzeczywistość ${ }^{29}$.

Kolejnym, już ostatnim rodzajem kłamstwa jest plotka. Wielu osobom plotkowanie sprawia radość, jest pewnego rodzaju rozrywką ${ }^{30}$. Plotkowanie powoduje również odczuwanie przyjemności. Plotka wzmacnia też więzi społeczne. Plotkowanie jest czynnością intymną i sekretną, odbywa się wśród osób, które darzą się zaufaniem - stąd osoba, z którą inicjator chce plotkować, może czuć się włączona do grupy czy do kręgu osób zaufanych ${ }^{31}$.

Jako plotkę rozumie się obmawianie osób nieobecnych, a także złośliwe pomówienia, które mogą prowadzić do zniesławienia danej osoby. Do najważniejszych źródeł plotki zalicza się ciekawość, ponieważ właśnie to, co nieznane, pobudza naszą wyobraźnię. Plotka, obgadywanie osób nieobecnych jest wymierzona $\mathrm{w}$ ich sprawy osobiste. Z plotką bardzo trudno walczyć i nie sposób jej zatrzymać, działa na zasadzie kuli śnieżnej i zawiera ziarenko prawdy. Kultura masowa nie sprzyja panowaniu nad plotką, ponieważ nie szanuje prywatności ludzi. Żywienie się niewiarygodnymi anegdotami i historyjkami gwiazd daje nam satysfakcję, radość i staje się lekiem na nudę. Plotka jest również sposobem na życie celebrytów, którzy wyznają zasadę: „o kim się nie pisze, ten nie istnieje”. Do negatywnych aspektów plotki zalicza się między innymi wzbudzanie przez nią zadowolenia z cudzego nieszczęścia ${ }^{32}$.

Plotka odpowiada na istniejące zapotrzebowanie, jedynym $\mathrm{z}$ warunków jej powstania jest to, by ludzie chcieli jej słuchać. Obecnie rozumienie

28 Por. W. Chudy, Filozofia kłamstwa..., dz. cyt., s. 411.

29 Por. W. Chudy, Filozofia kłamstwa..., dz. cyt., s. 413n.

30 Por. J. Mysona Byrska, Plotkujące społeczeństwo. Wady i zalety życia z plotką, „Mêlée. Kwartalnik Filozoficzno-Kulturalny" (2008), nr 4, s. 21 n.

31 Por. W. Chudy, Kłamstwo jako metoda, Warszawa 2007, s. 370-374.

32 Por. A. Zwoliński, Plotki i ploteczki. Informacja bez prawdy, Kraków 2006, s. 26-32. 
plotki odbiega od powszechnie przyjmowanej definicji tego pojęcia. Plotka traktowana jest jako zniekształcona prawda, której celem jest poprawianie dobrego samopoczucia osób uwielbiających sensację. Plotkarz przekazuje wieści o innych, a czyni to w klimacie samozadowolenia, ciesząc się, że nie jest taki jak bohater plotkowania. Plotka ma bardzo dużą siłę i odgrywa znaczącą rolę w życiu prywatnym i publicznym. Wiele plotkuje się o ludziach sławnych i popularnych, a także o politykach czy ludziach biznesu. To właśnie problemy, porażki i sukcesy tych osób stanowią o ich popularności plotki oraz wszelkiego rodzaju prasy i programów rozrywkowych. Plotkowanie daje satysfakcję i radość słuchaczom, ale również, jak już wspomniano, staje się sposobem na szczęśliwe i radosne życie gwiazd i celebrytów ${ }^{33}$. Należałoby zastanawić się, jakie znaczenie dla naszego samopoczucia ma sposób porozumiewania się. Według Stefana Garczyńskiego: „jedno jest pewne, że zarówno na prywatnym przyjęciu, jak i na posiedzeniu naukowym, w specjalistycznym czasopiśmie, popularnym magazynie największe zainteresowanie budzi nie ten, kto występuje $\mathrm{z}$ wiadomością, jakich wiele, $\mathrm{z}$ wystąpieniem podobnym do innych, ze swoją ostrożną, wyważoną opinią, ale ten, kto opowiadaniem wstrząsa, przynosi zdumiewające informacje lub przedstawia wystrzałowe teorie"34. Plotkowanie stawia w centrum zainteresowania nie tylko osoby, których plotka dotyczy, ale również plotkarzy, którzy te informacje przekazują dalej, sieją sensację i dają rozrywkę słuchaczom.

Plotka staje się również dobrym sposobem na zarabianie. Zapotrzebowanie na plotkarskie pisma wciąż rośnie, wiele tytułów sprzedaje informacje z życia znanych ludzi. Gwiazdy i sławy coraz częściej nie odbierają plotki jako czegoś negatywnego i nieeleganckiego, raczej z przyjemnością skupiają na sobie nieustanną uwagę innych. Plotka staje się częścią codziennych informacji. Nie jest ważne, czy informacje plotkarskie na temat danej osoby są pozytywne, czy też negatywne ważne, by były. Plotkę zarówno w sferze prywatnej, jak i w środkach

33 Por. E. Błachowicz, Plotka w świetle teorii aktów mowy i zasad etyki komunikacji międzyludzkiej, Rzeszów 2010, s. 50nn.

34 S. Garczyński, Skąd te błędy, Warszawa 1981, s. 32. 
masowego przekazu charakteryzuje również przyjemność obnażania słabości innych ludzi ${ }^{35}$.

W biznesie istnieje wiele specyficznych sytuacji, w których istnieje przyzwolenie na stosowanie kłamstw. Filozof Jarosław Kucharski w swoich rozważaniach na temat kłamstwa w etyce stosowanej, oprócz analizy wyżej wymienionych rodzajów kłamstwa, zwraca szczególną uwagę na kłamstwo w etyce biznesu. Szczególnie wyróżnia kłamstwo w negocjacjach, marketingowe oraz w rachunkowości.

Zasada prawdomówności jest bardzo często naruszana podczas negocjacji biznesowych, gdyż negocjacje to „odpowiednia strategia w przypadku różnych, a czasami sprzecznych interesów, dwóch stron współzależnych w takim stopniu, że porozumienie byłoby wzajemnie korzystne. Strony nie zgadzają się, ale pragnęłyby osiągnąć porozumienie, ponieważ zarówno brak rozwiązania, jak i współzawodnictwo byłyby dla obu niekorzystne" ${ }^{36}$. W negocjacji obie strony dążą do porozumienia, ponieważ mogą osiągnąć w ten sposób korzyści dla siebie. Niezależnie od celu negocjacji - czy dotyczy długoterminowego kontaktu lub sprzedaży, czy też innych działań biznesowych - w trakcie jej trwania istotne jest wypracowanie kompromisu pomiędzy oczekiwaniami stron. Obie strony muszą być przekonane o właściwej realizacji swoich interesów. Oczywiście idealną sytuacją byłoby doprowadzenie do maksymalnej obustronnej korzyści z wynegocjowanego kontraktu ${ }^{37}$.

Najciekawszym przykładem kłamliwego sprzedawcy wydaje się być pośrednik w sprzedaży używanych samochodów. Jego zadaniem jest przekonać klienta, że trafił na rewelacyjną okazję zarówno cenową, jak również jeśli chodzi o stan techniczny pojazdu. Bardzo często za pomocą kłamstw przekonuje się klienta, że samochód, który zamierza kupić, jest wyjątkowym egzemplarzem. Pojawia się w tym wypadku problem kłamliwego

35 Por. E. Błachowicz, Plotka w świetle teorii aktów mowy i zasad etyki komunikacji międzyludzkiej, dz. cyt., s. 53, 57.

36 J. Kucharski, Usprawiedliwione kłamstwo we współczesnej etyce stosowanej, dz. cyt., s. 193, cyt. za: W. Mastenbroek, Negocjacje, tłum. E. i T. Szapiro, Warszawa 1998, s. 11.

37 Por. J. Kucharski, Usprawiedliwione kłamstwo we wspótczesnej etyce stosowanej, dz. cyt., s. 194. 
przekazywania informacji, bardzo często fałszowane są dane dotyczące wieku lub przebiegu samochodu, aby otrzymać jak najwięcej korzyści dla siebie i swojej firmy. Niestety w wielu branżach wręcz oczekuje się od sprzedających tzw. „koloryzowania”, ponieważ sprzedawcy, którzy informują klientów o tym, że mówią prawdę, najczęściej tracą na tej swojej uczciwości ${ }^{38}$. Jarosław Kucharski w swoich rozważaniach przytacza następujący przypadek: „Niedaleko siebie działały dwa komisy samochodowe. Właściciel jednego z nich uznał, że będzie uczciwie informował klientów o historii, przejechanych kilometrach i innych wadach i zaletach oferowanego towaru. Właściciel drugiego działał zgodnie ze stereotypem, czyli okłamywał klientów («podkręcał» liczniki przejechanych kilometrów, zaniżał wiek samochodów, maskował drobne usterki). Wydawałoby się, że klienci powinni korzystać z usług tego, który starał się być uczciwy. W rzeczywistości jednak uczciwy sprzedawca musiał zamknąć firmę, a nieuczciwy prosperuje dalej. Klienci woleli być okłamywani i starali się wierzyć w kłamstwa, niż być konfrontowani z prawdą" ${ }^{39}$. Wydaje się, że ten autentyczny przypadek wskazuje na specyficzne oczekiwania klientów. Paradoksalnie kłamstwo bardziej się opłaca i daje korzyści i radość zarówno sprzedającemu, jak również kupującemu towar.

Obecnie powszechne staje się wynajmowanie biegłego negocjatora. Podczas negocjacji bardzo często strony posługują się różnymi technikami, w których wykorzystują fałszywe informacje, próbują wprowadzać drugą stronę w błąd. Jeśli obie strony są wyspecjalizowanymi i wyszkolonymi negocjatorami, to bardzo dobrze znają techniki, którymi się posługują, wiedzą, czego mogą spodziewać się od interlokutora, jednak gdy negocjacje prowadzone są z osobą, która nie ma wiele wspólnego $\mathrm{z}$ negocjowaniem, w takim wypadku ta ostatnia jest na straconej pozycji. Według Kucharskiego kłamstwo jest jedną z reguł negocjowania, s. 195.

38 Por. J. Kucharski, Usprawiedliwione kłamstwo we współczesnej etyce stosowanej, dz. cyt.,

39 J. Kucharski, Usprawiedliwione kłamstwo we współczesnej etyce stosowanej, dz.cyt., s. 195, cyt. za: opis przypadku zawarty w liście zamieszczonym w artykule B. Korzeniowskiego, Handlarze oszukuja, bo tego oczekujemy, http://moto.onet.pl/aktualnosci/ handlarze-oszukuja-bo-tegooczekujemy/e15bk (15.11.2013). 
wręcz wskazane jest nieujawnianie prawdziwych oczekiwań na początku negocjowania. Posuwa się nawet do stwierdzenia, że dzięki kłamstwom negocjacje przebiegają szybciej i sprawniej. Kłamstwo jest częścią praktyki negocjacyjnej, a rezygnacja $z$ niego przyniosłaby więcej kosztów niż zysków. A to właśnie zysk daje szczęście i radość, szczególnie w obszarze biznesu. Jednak bardzo często dochodzi również do pewnych nieporozumień, zwłaszcza podczas negocjacji międzykulturowych. To, co dla jednej strony może być kłamstwem, dla drugiej może oznaczać tylko niewinne otwarcie negocjacji ${ }^{40}$. Chociaż negocjacje mogą przynieść wiele korzyści nawet obu stronom, to wyróżnia się dwie sytuacje, w których raczej nie usprawiedliwia się kłamstwa w taktykach negocjacyjnych. Po pierwsze - gdy pomiędzy stronami negocjacji istnieje szczególna więź, przyjaźń, ponieważ skutkuje to naruszeniem zaufania, oraz po drugie gdy strona przeciwna jest znacząco słabsza, ponieważ ta słabość świadczy szczególnie o braku biegłości w technikach i taktykach negocjacyjnych. Posługiwanie się kłamstwem w takiej sytuacji powinno godzić w nasze uczucie przyzwoitości.

Kucharski proponuje stosowanie zasady wzajemnej korzyści, która miałaby regulować stosowanie kłamstwa podczas praktyk negocjacyjnych. Filozof cytuje za Alanem Strudlerem: „Możliwość kłamania w trakcie negocjacji pomaga rozwiązać problem, który jest negocjowany; powoduje więc korzyść, dostarczając bezpiecznego środka komunikacji, z którego obie strony mogą korzystać. [...] W okolicznościach, gdzie obie strony są kompetentne i mają świadomość obowiązujących je konwencji, każda ze stron ma taką samą możliwość zdobycia informacji od drugiej i żadna nie może zdobyć w tym zakresie przewagi"41. Oczywiście wzajemną korzyść z kłamstwa mogą osiągnąć wyłącznie profesjonalni negocjatorzy, $\mathrm{w}$ wypadku negocjowania $\mathrm{z}$ niewyspecjalizowanymi osobami stosowanie tej zasady doprowadzi do nieuprawnionej jednostronnej przewagi.

\footnotetext{
40 Por. J. Kucharski, Usprawiedliwione kłamstwo we wspótczesnej etyce stosowanej, dz. cyt., s. 198-205.

41 J. Kucharski, Usprawiedliwione kłamstwo we współczesnej etyce stosowanej, dz.cyt., s. 207, cyt. za: A. Strudler, On the ethics of deception in negotiation, [w:] What's fair? Ethics for negotiatiors, eds. C. Menkel-Meadow, M. Wheeler, San Francisco 2004, s. 141.
} 
Kolejnym przykładem kłamstwa w biznesie jest kłamstwo marketingowe. Zastanawiając się nad kłamstwem marketingowym, należy na wstępnie zdefiniować, czym jest reklama. Przekaz reklamowy to „przekaz [...] mający na celu zwiększenie zbytu produktów, inną formę korzystania z nich lub inny efekt, który jest pożądany przez reklamodawcę"42. Oczywiście Kodeks etyki reklamy reguluje działania marketingowe, tym samym zabraniając intencjonalnego wprowadzania w błąd, w szczególności w odniesieniu do wartości produktu, warunków dostawy i gwarancji oraz wszelkich istotnych faktów, których przemilczenie mogłoby zaszkodzić klientom. Pomimo tych regulacji można jednak wyróżnić trzy obszary kłamstwa dostrzegalnego w reklamie. Po pierwsze jest to kłamstwo niedopuszczalne, czyli obietnica korzyści, którym reklamowane dobro nie będzie w stanie sprostać. Po drugie - rozbieżność pomiędzy przekazem a faktem, to znaczy sytuacja, gdy dobro reklamowane jest jako środek uniwersalny, a tymczasem obiecywane korzyści może przynieść tylko podczas odpowiedniego stosowania i w przypadku zaistnienia ściśle określonej potrzeby. Po trzecie - rozbieżność pomiędzy przekazem a przekonaniami, gdy reklama ma na celu wywołanie błędnego przekonania u odbiorcy. Taka zwodnicza reklama wprowadza w błąd swoją grupę docelową. Podobnie jak w przypadku innych rodzajów kłamstw, dopóki kłamstwo reklamowe nie zostanie wykryte, może spowodować wiele radości i stać się czymś dobroczynnym dla adresata reklamy. Odbiorcy wydaje się, ze reklamodawca wie lepiej, co jest dla niego dobre, i próbuje uchronić go przed złym wyborem (na przykład przed paleniem papierosów), chociaż bardzo często jest to przykład sztucznego kreowania nowych potrzeb u konsumentów, aby zwiększyć sprzedaż ${ }^{43}$. Wydaje się, że jedynym dopuszczalnym rodzajem kłamstwa w reklamie jest kłamstwo żartobliwe (przykład reklamy: „Red bull doda ci skrzydeł”), które może poprawić humor i rozbawić odbiorcę, nie wprowadzając go w błąd.

42 Por. Kodeks etyki reklamy, Rada Reklamy, Warszawa 2006, http://www.radareklamy. org/kodeks-etyki-reklamy.html (15.11.2013).

43 Por. J. Kucharski, Usprawiedliwione kłamstwo we wspótczesnej etyce stosowanej, dz. cyt., s. 209-216. 
Ostatnim przykładem kłamstwa w biznesie, o którym pisze Kucharski, jest fałszowanie ksiąg rachunkowych, aby ukryć rzeczywistą kondycję firmy dla osiągnięcia korzyści. Głównym motywem stosowania „twórczej księgowości" jest zysk dla firmy lub przedsiębiorstwa czy też sztuczne podniesienie wartości firmy, aby wprowadzić w błąd akcjonariuszy ${ }^{44}$. Można zauważyć, że kłamstwo w biznesie jest równie częste, jak w życiu codziennym, jednak radość i szczęście wypływające z kłamstwa w tym przypadku skupiają się głównie na korzyściach i zyskach, jakie może ono dać zainteresowanym.

Podsumowując, do uczuć pozytywnych sprzyjających kłamstwu należą radość i szczęście z oszukiwania innych ludzi. Szczęście jest to pozytywna emocja, pomyślność, radosne przeżycie, spowodowane doświadczeniami ocenianymi przez podmiot jako pozytywne i prawdziwe. Szczęście może być wynikiem jakiegoś wydarzenia, które wpływa pozytywnie na bieg naszego życia, tym samym powodując pozytywne odczucia ${ }^{45}$.

Jeśli chodzi o radość czy szczęście wypływające z kłamstwa, to po pierwsze czerpiemy je z samego faktu, że udało nam się kogoś oszukać. Kłamanie zwiększa wydzielanie adrenaliny. Daje poczucie wyższości, spełnienia. Profesor Paul Ekman, jeden z najbardziej znanych naukowców zajmujących się wykrywaniem kłamstw, nazwał to uczucie radością oszukiwania. Taka radość oszukiwania towarzyszy m.in. na przykład uczniom, kiedy zaliczą test, ściągając, i dzieciom, którym uda się primaaprilisowy żart. Tego typu niedomówienia towarzyszą nam w codziennym życiu: bez mrugnięcia okiem zachwycamy się najbrzydszym obrazem, jaki w życiu widzieliśmy, świętujemy awans kolegi na stanowisko, na które sami mieliśmy nadzieję się dostać, śmiejemy się ze słabego dowcipu ${ }^{46}$.

Po drugie kłamiemy, ponieważ chcemy, aby inni uważali, że nam się dobrze powodzi, a nawet że powodzi nami się nam lepiej niż innym. Na

\footnotetext{
44 Por. J. Kucharski, Usprawiedliwione kłamstwo we współczesnej etyce stosowanej, dz. cyt., s. $217-222$.

45 Por. J. Dalke i in., Czym jest szczęście? Analiza zagadnienia na podstawiekoncepcji Władysława Tatarkiewicza, „Analiza i Egzystencja” 21 (2013), s. 150.

46 M. Maciejewska, Kłamię, bo muszę, więc jestem, http://www.focus.pl/czlowiek/klamie-bo-musze-wiec-jestem-7804 (19.04.2015).
} 
przykład mężczyźni zaczesują „pożyczkę” (jakby ktokolwiek mógł się na to nabrać) i kupują drogie samochody, by przekonać innych o swoim wysokim statusie (nie wspominają o komorniku, który puka do drzwi w związku z zaległościami w spłacie kredytu na auto). Szczęśliwych udajemy przed innymi ${ }^{47}$.

Po trzecie należy wyróżnić szczęście i radość osoby okłamanej, która uznaje przekazane informacje za prawdziwe. Kłamstwo staje się bardzo powszechne, a co więcej - zaczynamy czerpać z niego satysfakcję, na przykład komplementy odczuwamy jako miłe, więc wierzymy w nie dość często, nie weryfikując wszystkich danych, jakie usłyszymy od naszych rozmówców. Chociaż takie otaczanie się kłamstwem jest trudne, wydaje się, że jeszcze bardziej problematyczne stałoby się życie wśród radykalnie szczerych osób. Wyobraźmy sobie, że od znajomego słyszymy: „nie przychodź więcej, bo strasznie nudzą mnie twoje opowieści o problemach z dziećmi”, „te pięć kilogramów, które ostatnio przytyłaś, jak zwykle poszło ci w biodra" ${ }^{48}$.

Po czwarte kłamiemy na dany temat, ponieważ chcemy uszczęśliwić innych. W tym momencie szczęście będzie rozumiane jako unikanie cierpienia i niepokoju. Ważna staje się przyjemność aktualna, a nie długofalowa perspektywa.

Za Tatarkiewiczem można stwierdzić, że podstawowym kryterium szczęścia jest zadowolenie z własnego życia. Według autora szczęście to trwałe i pełne zadowolenie $z$ życia ${ }^{49}$. Na prawdzie opieramy swoje poznanie, a jeśli za prawdę uznamy coś, co jest fałszem, to nasze działanie może stać się nieskuteczne. Prawda jest niezmienna, pewna, stabilna, jednoznaczna, ale według Wojciecha Chudego także nudna. Kłamstwo to nowy poziom rzeczywistości zbudowany przez kłamcę. Kłamstwo jest kolorowe i ciekawe oraz, jak zauważyliśmy, może dać nam radość, ale należy pamiętać, że okłamany człowiek może spaść z poziomu kłamstwa

47 M. Maciejewska, Kłamię, bo muszę, więc jestem, dz. cyt.

48 M. Maciejewska, Kłamię, bo muszę, więc jestem, dz. cyt.

49 M. Pepliński, Władysława Tatarkiewicza analiza terminu szczęście, „Rocznik Komisji Filozofii Bydgoskiego Towarzystwa Naukowego Filo-sofija” 2-3 (2011), nr 13-14, s. 674. 
i wtedy „mocno się potłuc” i rozczarować. Na kłamstwie nie zbudujemy trwałego szczęścia, to mogą być jedynie krótkotrwałe, ulotne zadowolenie, radość, uniknięcie cierpienia czy niezadowolenia. Poza tym poruszamy się wówczas na innym poziomie rzeczywistości. Osoba oszukana nie zna prawdy, dlatego poprzez kłamstwo nie może uzyskać szczęścia jako stanu trwałego, lecz jedynie jako moment, krótkotrwały czas, a nawet chwilową poprawę humoru, zadowolenie. Zawsze towarzyszy temu ryzyko, że kłamstwo zostanie zdemaskowane.

\section{Bibliografia}

Antas J., O kłamstwie i kłamaniu, Kraków 2000.

Błachowicz E., Plotka wświetle teorii aktów mowy i zasad etyki komunikacji międzyludzkiej, Rzeszów 2010.

Chudy W., Filozofia kłamstwa. Kłamstwo jako fenomen zła w świecie osób i społeczeństw, Warszawa 2003.

Chudy W., Kłamstwo jako metoda, Warszawa 2007.

Dalke J. i in., Czym jest szczęście? Analiza zagadnienia na podstawie koncepcji Władysława Tatarkiewicza, „Analiza i Egzystencja” 21 (2013), s. 149-160.

Freud S., Kultura jako źródło cierpień, tłum. J. Prokopiuk, Warszawa 1995.

Garczyński S., Skąd te błędy, Warszawa 1981.

Goffman E., Człowiek w teatrze życia codziennego, tłum. H. Danter-Śpiewak, Warszawa 2000.

Kodeks etyki reklamy, Rada Reklamy, Warszawa 2006, http://www.radareklamy.org/ kodeks-etyki-reklamy.html (15.11.2013).

Korzeniowski B., Handlarze oszukuja, bo tego oczekujemy, http://moto.onet.pl/aktualnosci/ handlarze-oszukuja-bo-tego-oczekujemy/e15bk (15.11.2013).

Kucharski J., Usprawiedliwione kłamstwo we wspótczesnej etyce stosowanej, Kraków 2014. Maciejewska M., Kłamię, bo muszę, więc jestem, http://www.focus.pl/czlowiek/klamie-bo-musze-wiec-jestem-7804 (19.04.2015).

Mastenbroek W., Negocjacje, tłum. E. i T. Szapiro, Warszawa 1998.

Mysona Byrska J., Plotkujace społeczeństwo. Wady i zalety życia z plotką, „Mêlée. Kwartalnik Filozoficzno-Kulturalny" (2008), nr 4, s. 21-29. 
Pepliński M., Władysława Tatarkiewicza analiza terminu szczęście, „Rocznik Komisji Filozofii Bydgoskiego Towarzystwa Naukowego Filo-sofija" 2-3 (2011), nr 13-14, s. 663-674.

Stownik jezzyka polskiego, red. M. Szymczak, Warszawa 1978.

Strudler A., On the ethics of deception in negotiation, [w:] What's fair? Ethics for negotiatiors, eds. C. Menkel-Meadow, M. Wheeler, San Francisco 2004.

Św. Tomasz z Akwinu, Suma teologiczna, t. 20, tłum. F. W. Bednarski, Londyn 1972.

Walters S. B., Kłamstwo cała prawda o... Jak wykryć kłamstwo i nie dać się oszukać, tłum. E. Jusewicz-Kalter, Gdańsk 2003.

White N., Filozofia szczęścia od Platona do Skinnera, tłum. M. Chojnacki, Kraków 2008. Witkowski T., Psychologia kłamstwa. Motywy - strategie - narzędzie, Warszawa 2002. Zwoliński A., Plotki i ploteczki. Informacja bez prawdy, Kraków 2006. 